Provided for non-commercial research and education use. Not for reproduction, distribution or commercial use.

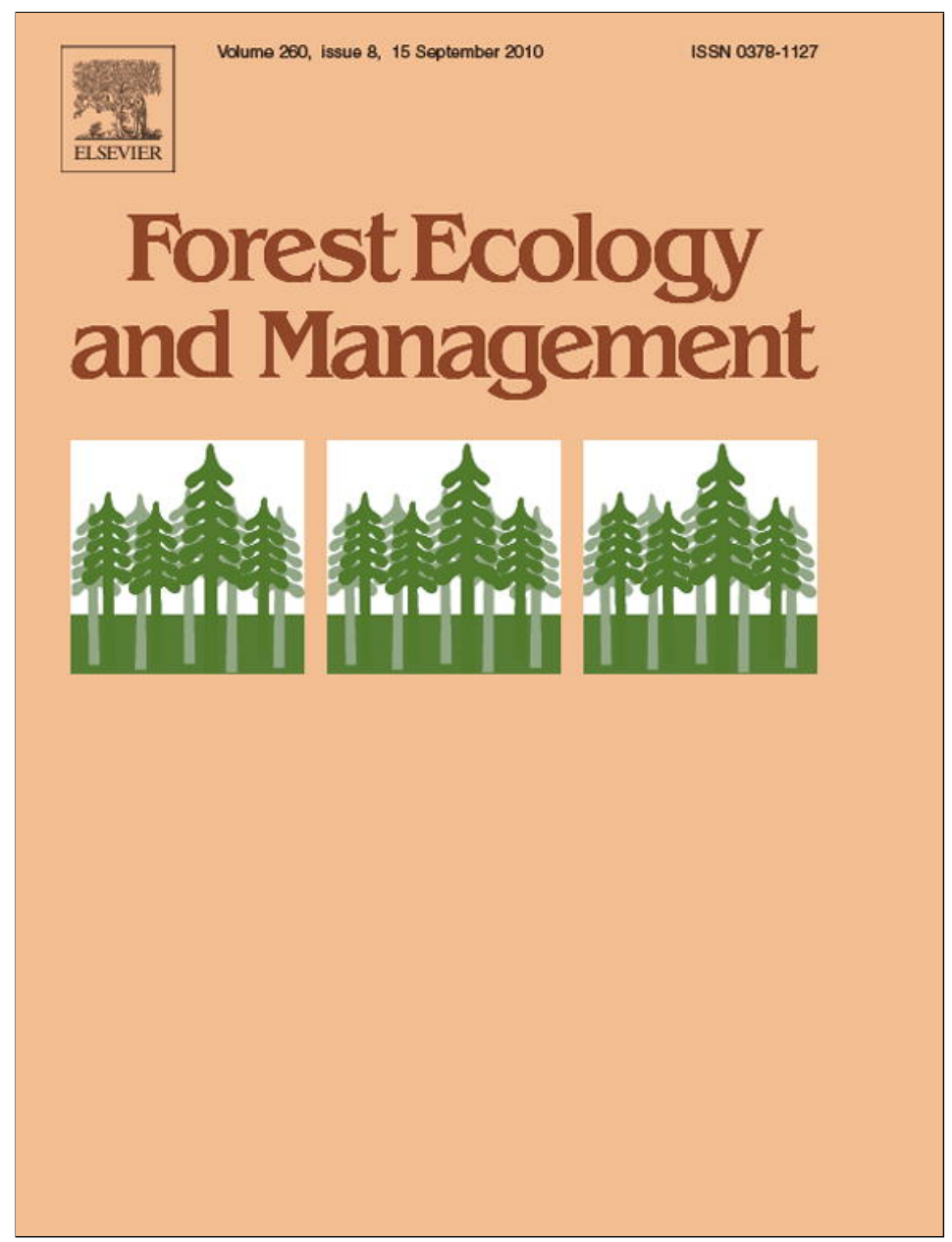

This article appeared in a journal published by Elsevier. The attached copy is furnished to the author for internal non-commercial research and education use, including for instruction at the authors institution and sharing with colleagues.

Other uses, including reproduction and distribution, or selling or licensing copies, or posting to personal, institutional or third party websites are prohibited.

In most cases authors are permitted to post their version of the article (e.g. in Word or Tex form) to their personal website or institutional repository. Authors requiring further information regarding Elsevier's archiving and manuscript policies are encouraged to visit:

http://www.elsevier.com/copyright 


\title{
Does afforestation increase bird nest predation risk in surrounding farmland?
}

\author{
Luís Reino $^{\mathrm{a}, \mathrm{b}, \mathrm{c}, *}$, Miguel Porto $^{\mathrm{d}}$, Rui Morgado ${ }^{\mathrm{b}, \mathrm{e}}$, Filipe Carvalho $^{\mathrm{f}}$, António Mira $^{\mathrm{f}}$, Pedro Beja $^{\mathrm{c}}$ \\ a Centro de Estudos Florestais, Instituto Superior de Agronomia, Univ. Técnica de Lisboa, Tapada da Ajuda, 1349-017 Lisboa, Portugal \\ b ERENA, Ordenamento e Gestão de Recursos Naturais SA, Rua Robalo Gouveia, 1-1A, 1900-392 Lisboa, Portugal \\ ' CIBIO-Centro de Investigação em Biodiversidade e Recursos Genéticos, Universidade do Porto, Campus Agrário de Vairão, Rua Padre Armando Quintas, 4485-661 Vairão, Portugal \\ d Centro de Biologia Ambiental, Departamento de Biologia Vegetal, Faculdade de Ciências de Lisboa, Universidade de Lisboa, C2 Campo Grande, $1749-016$ Lisboa, Portugal \\ e Centro de Ecologia Aplicada "Prof. Baeta Neves", Instituto Superior de Agronomia, Universidade Técnica de Lisboa, Tapada da Ajuda, 1349-017, Portugal \\ ${ }^{\mathrm{f}}$ Unidade de Biologia da Conservação, Grupo de Ecossistemas e Paisagens Mediterrânicas - Instituto de Ciências Agrárias Mediterrânicas, Universidade de Évora - Núcleo da Mitra, \\ Apartado 94, 7002-554 Évora, Portugal
}

\section{A R T I C L E I N F O}

Article history:

Received 24 March 2010

Received in revised form 13 July 2010

Accepted 18 July 2010

\section{Keywords:}

Conservation

Edge effects

Forest plantations

Grassland birds

Habitat fragmentation

Mediterranean farmland

\begin{abstract}
A B S T R A C T
Afforestation of agricultural land is increasingly used to deliver environmental benefits, but their effects on biodiversity remain poorly understood. This paper tests the hypothesis that afforestation changes predation processes in surrounding farmland, examining how the characteristics and landscape context of forest plantations affect predator (birds and mammalian carnivores) and key prey (rabbits and hares) abundances, and bird nest predation rates in Iberian cereal-steppes. Lagomorphs and predators were surveyed in fallow fields around 50 forest plantations, where predation rates were estimated using artificial nests set at $0,100,200$ and $300 \mathrm{~m}$ from the forest edge. Recent plantations structurally similar to sparse (oak) or dense (pine) shrublands were associated with the highest hare and rabbit abundances, respectively, whereas both species avoided landscapes with high eucalyptus cover. In contrast, mature eucalyptus plantations showed strong positive effects on typical nest predators such as corvids and carnivores. Open farmland fragmentation favoured the abundance of lagomorphs and carnivores. Despite these effects and the high predation rate on artificial nests (49\%), there was neither evidence for increased predation near plantation edges nor higher predation in fields with more lagomorphs and predators. However, predation tended to increase with cover by young oak plantations and overall forest plantation cover, to decrease with eucalyptus cover at both the local and landscape scales, and to peak in landscapes with intermediate edge densities. These results suggest that afforestation may have strong effects on bird nest predation rates by changing landscape composition and configuration, rather than by inducing local increases in predator and prey populations. Nevertheless, increased abundances of generalist predators associated with forest plantations may still be considered of conservation concern, thus supporting the recommendation for strongly restricting afforestation in areas important for open grassland birds. Where this is unavoidable, monitoring should be undertaken to provide early signals for bird population declines associated with predator increases, eventually triggering conservation action such as predator exclusion or removal.
\end{abstract}

(c) 2010 Elsevier B.V. All rights reserved.

\section{Introduction}

Afforestation of former arable land is often used to deliver environmental benefits such as natural habitat restoration (Santos et al., 2006), reductions in soil erosion and surface runoff (GarcíaRuiz et al., 1996), and improvements in water quality (Hansen et al., 2007). Climate change has further increased the interest for large scale afforestation, as a tool to reduce atmospheric concen-

\footnotetext{
* Corresponding author at: CIBIO-Centro de Investigação em Biodiversidade e Recursos Genéticos, Universidade do Porto, Campus Agrário de Vairão, Rua Padre Armando Quintas, 4485-661 Vairão, Portugal. Tel.: +351 252660411.

E-mail address: luis.reino@mail.icav.up.pt (L. Reino).
}

trations of carbon dioxide (Niu and Duiker, 2006). However, fears have been expressed that afforestation could negatively impact on biodiversity (Caparrós and Jacquemont, 2003; Stoate et al., 2009), mostly by replacing grassland, cropland and shrubland habitats of high conservation relevance with forest plantations inhabited with widespread species (Díaz et al., 1998; Shochat et al., 2001; Oxbrough et al., 2006). Afforestation also changes the amount and configuration of open habitats at the landscape scale, and may result in fragmentation and edge effects outside the area actually planted with trees (Ries et al., 2004; Ewers and Didham, 2006). Information to assess such effects is generally lacking (but see Bieringer and Zulka, 2004; Reino et al., 2009), but is essential to ensure that afforestation programmes do not adversely impact on biodiversity. 
One way in which afforestation can affect animal - and particularly bird-populations is through predation (e.g., Evans, 2004). Forest plantations may offer refuges for generalist predators, such as corvids and medium-sized carnivores, that otherwise would be absent or less abundant in open country, thereby increasing predation rates in surrounding habitats (Andrén, 1992; Pita et al., 2009). Also, afforestation may favour key prey such as lagomorphs (Hulbert et al., 1996), which in turn may increase predator activity and thus predation rates (Yanes and Suárez, 1996). Predation increases may also be expected from habitat fragmentation and the proliferation of edges associated with forest plantations, because predator abundance and activity is often higher in fragmented landscapes and close to habitat edges (Chalfoun et al., 2002). Losses of nest contents and adults to predators might eventually lead to population declines of vulnerable species (Yanes and Suárez, 1996; Fletcher et al., 2010). Non-lethal effects may also be relevant (Cresswell, 2008), as perceived predation risk may induce individuals to avoid breeding or foraging near wooded edges and in small patches (Ribic et al., 2009 and references therein), thereby causing reductions in the amount of usable habitat that are much larger than the area effectively occupied by forest plantations (Reino et al., 2009). However, although some species of conservation concern show avoidance of forest edges (Stroud et al., 1990; Reino et al., 2009), others may show no avoidance or even preference for this habitat type (Avery, 1989; Reino et al., 2009, 2010). Also, while many studies have documented increased predation rates at habitat edges (review in Batáry and Báldi, 2004), such an effect was not found by studies focusing specifically on forest plantations (Avery et al., 1989). Further research is needed to better understand the environmental costs and benefits of afforestation, particularly in areas occupied by species of conservation concern.

The Iberian cereal-steppes are among the highest value landscapes for grassland bird conservation in Europe (Bota et al., 2005). Afforestation of this landscape has increased over the past decades, following a long-term trend of rural depopulation and agricultural abandonment (Van Doorn and Bakker, 2007), and increased grant aiding for afforestation of marginal agricultural land (Stoate et al., 2009). These forest plantations have negative impacts by excluding species of conservation concern associated with open pastures and dry cereal cropland (Díaz et al., 1998; Bota et al., 2005). Negative effects also extend beyond forest boundaries, because at least some grassland birds strongly avoid forest edges (Reino et al., 2009) and occur at much reduced densities in fragmented landscapes (Brotons et al., 2005; Moreira et al., 2005; Morgado et al., 2010). Previous studies suggested that avoidance of forested habitats may, at least in part, be shaped by predation risk, particularly during the breeding season (Reino et al., 2009; Morgado et al., 2010), because woody habitats may increase both predator abundances (Pita et al., 2009) and nest predation rates (Pescador and Peris, 2001). Furthermore, ground-nesting birds suffer high nest predation rates (Yanes and Suárez, 1995), and so increased densities of generalist predators may result in decreased body condition of breeding birds (Suárez et al., 2005a,b), and even population declines (Yanes and Suárez, 1996). Despite this, studies have yet to show a link between forest plantations, predator and prey abundances, and nest predation rates.

This study investigates how forest plantations affect predator assemblages and bird nest predation rates in cereal-steppe landscapes with different amounts and configuration of open and forested habitats. The effects of forest plantations on lagomorphs were also analysed, because previous studies showed a link between their abundance and bird nest predation rates in Mediterranean shrubsteppes (Yanes and Suárez, 1996). Specifically, the study tested the following predictions: (i) lagomorph and predator abundances increase with both cover by forest plantations and fragmentation of open habitats; (ii) bird nest predation rates are higher near forest plantation edges and are positively related to forest plantation cover and fragmentation of open habitats; (iii) bird nest predation rates increase with the abundance of lagomorphs and nest predators associated with forest plantations and fragmented landscapes.

\section{Methods}

\subsection{Study area}

The study was conducted in Southern Portugal, mostly within the Special Protection Area (SPA) of Castro Verde, designated under European Directive 79/409/EEC to protect grassland birds. The climate is Mediterranean, with hot summers (averaging $24^{\circ} \mathrm{C}\left[16-32^{\circ} \mathrm{C}\right]$ in July), mild winters $\left(9^{\circ} \mathrm{C}\left[5-14^{\circ} \mathrm{C}\right]\right.$ in January), and $>75 \%$ of annual rainfall $(500-600 \mathrm{~mm})$ concentrated in October-March. The landscape is flat or gently undulating (100-300 ma.s.l.) and dominated by an agricultural mosaic of cereal, fallow and ploughed fields, created by rotational dry cereal cultivation. Until recently, tree cover was largely restricted to some eucalyptus (Eucalyptus sp.) plantations (usually 40-60 years old) and open holm oak (Quercus rotundifolia) woodlands grazed by livestock. Afforestation with umbrella pines (Pinus pinea) and holm and cork oaks (Quercus suber) has increased since the early 1990s due to EU subsidies, mainly in the periphery of the SPA. Details of the study area are reported elsewhere (Delgado and Moreira, 2000; Moreira et al., 2005; Reino et al., 2009, 2010).

\subsection{Study design}

Predator surveys and predation experiments were carried out on fallow fields adjacent to forest plantations of varying sizes ( $<1.0$ ha to $>100$ ha), embedded in landscapes with variable amounts of forested habitats $(<1.0 \%$ to $>50 \%)$, based primarily on $300-\mathrm{m}$ transects perpendicular to the forest edge (Reino et al., 2009). The study focused on fallow fields, because they are particularly important for grassland birds (Delgado and Moreira, 2000; Reino et al., 2010), and to reduce variation among sites unrelated to forest and landscape features (Reino et al., 2009). Sampling sites were selected according to Reino et al. (2009), involving the identification of all forest plantations from land cover maps (http:// www.igeo.pt/IGEO/portugues/produtos/inf_cartografica.htm) and systematic field surveys. Each forest patch was defined as a discrete tree plantation surrounded by open farmland habitats, and it was selected if it was adjacent to a fallow field at least $600 \mathrm{~m}$ long and $300 \mathrm{~m}$ wide, to allow sampling open habitats at distances up to $300 \mathrm{~m}$ from the nearest forest edge. A few patches with sparse tree cover and trees in poor condition were discarded from selection because they corresponded to abandoned plantations, and so their use together with plantations under regular forest management could be a potential source of bias. The selection procedure yielded 50 forest plantations, spanning a wide range of plantation types, ages and sizes (Table 1). Only the largest fallow field was sampled per forest patch and the mean nearest distance between sampled fields was $2218 \pm 1291 \mathrm{~m} \mathrm{SD}$ (658-6338 m), to reduce problems of pseudo-replication and spatial autocorrelation, while maintaining a sufficiently large sample size.

\subsection{Explanatory variables}

Analyses were based on sixteen variables reflecting forest and landscape characteristics (Table 1 ). In addition, we used two variables coding the $X$ (Northing) and $Y$ (Easting) Cartesian coordinates of sampling sites to account for unmeasured spatially structured factors, thereby explicitly dealing with eventual spatial trends in 
Table 1

Description and summary statistics of variables used to examine the influence of habitat conditions on lagomorph and predator abundance, and nest predation rates in southern Portugal (April-July 2005).

\begin{tabular}{|c|c|c|c|c|c|}
\hline Variable (unit) & Description & Transformation & Mean & SD & Range \\
\hline \multicolumn{6}{|l|}{ Forest plantation attributes } \\
\hline Eucalyptus plantations & Binary variable coding eucalyptus plantations & - & 0.2 & 0.4 & $0-1$ \\
\hline Pine plantations & Binary variable coding umbrella pine plantations & - & 0.3 & 0.5 & $0-1$ \\
\hline Oak plantations & Binary variable coding cork and holm oak plantations & - & 0.5 & 0.5 & $0-1$ \\
\hline Plantation age (years) & Age of forest plantation & Logarithmic & 14.4 & 13.6 & $1-60$ \\
\hline Plantation area (ha) & Area of forest plantation & Logarithmic & 45.6 & 34.1 & $0.7-123.3$ \\
\hline \multicolumn{6}{|l|}{ Edge contrast } \\
\hline Tree density (trees/m) & $\begin{array}{l}\text { Density of trees at the border between forest plantations and farmland } \\
\text { fields }\end{array}$ & Logarithmic & 0.3 & 0.2 & $0-0.8$ \\
\hline Tree height (m) & $\begin{array}{l}\text { Mean tree height at the border between forest plantations and farmland } \\
\text { fields }\end{array}$ & Logarithmic & 3.7 & 4.5 & $0-17.3$ \\
\hline Farmland trees & $\begin{array}{l}\text { Binary variable coding the presence of isolated trees in adjacent } \\
(<300 \mathrm{~m}) \text { farmland }\end{array}$ & - & 0.3 & 0.5 & $0-1$ \\
\hline \multicolumn{6}{|l|}{ Landscape context } \\
\hline Eucalyptus plantations cover (\%) & Proportion of area within 1-km radius with eucalyptus plantations & Angular & 3.0 & 5.5 & $0-23.6$ \\
\hline Pine plantations cover $(\%)$ & Proportion of area within 1-km radius with pine plantations & Angular & 7.0 & 10.2 & $0-39.4$ \\
\hline Oak plantations cover $(\%)$ & Proportion of area within 1-km radius with oak plantations & Angular & 12.6 & 12.4 & $0-36.1$ \\
\hline Total forest plantations cover (\%) & Proportion of area within 1-km radius with forest plantations & Angular & 22.5 & 11.8 & $0.4-51.9$ \\
\hline Open holm oak woodlands cover (\%) & Proportion of area within 1-km radius with open holm oak woodlands & Angular & 7.7 & 11.1 & $0-45.7$ \\
\hline Mean patch size (ha) & Mean size of forest patches & Logarithmic & 134.3 & 88.1 & $7.7-304.1$ \\
\hline Edge density $\left(\mathrm{km} / \mathrm{km}^{2}\right)$ & Density of forest edges & Logarithmic & 4.0 & 1.1 & $1.1-7.8$ \\
\hline Patch shape complexity & Area Weighed Mean Shape Index (AWMSI) & Logarithmic & 2.2 & 0.6 & $1.3-4.1$ \\
\hline
\end{tabular}

the response variables unrelated to forest and landscape variables (Legendre and Legendre, 1998).

Forest plantations were characterized according to variables coding the dominant tree species and the age and area of the plantation, whereas edge contrast (sensu Ries et al., 2004) between forest and adjacent open fields was estimated from the height and density of trees at forest boundaries, assuming that taller and denser plantations corresponded to higher edge contrasts. These variables were computed from digital photographs taken at known distances (usually 70-90 m), perpendicularly to the forest edge. Presence of trees in the agricultural matrix was taken as an indicator of softer forest-farmland transitions. Landscape composition and fragmentation metrics were estimated within $1-\mathrm{km}$ radius circles of each sampling point located at the forest edge, from digital land cover maps prepared using aerial photography and field surveys. Fragmentation was estimated from the mean size, edge density and shape complexity (AWMSI) of open arable patches, computed using the Patch Analyst extension for ArcView (Rempel and Carr, 2003; see Reino et al., 2009, for details).

\subsection{Predator surveys}

Potential avian nest predators such as egrets, storks, most birds of prey, and corvids were surveyed at fields adjacent to forest plantations, simultaneously with overall bird counts (Reino et al., 2009) and bird nest predation experiments. In each field, point-transect surveys were conducted twice (April and May 2005), with 10-min counts at $0,100,200$ and $300 \mathrm{~m}$ from the forest edge, following standard procedures (Bibby et al., 2000; Reino et al., 2009). Two additional counts were made in May 2005 along the same 300$\mathrm{m}$ transects, during visits to set and check the bird nest predation experiment (see below). During each visit, the initial position and subsequent movements of all avian predators using the field and the forest plantation edges were mapped, and the minimum number of individuals of each species was estimated, with care taken to avoid double-counts. The mean count of each species across the four visits was then used to derive indices of predator activity at each field. Combining data across counts was necessary to increase sample sizes for a diverse array of avian predators, thereby providing a reasonable estimate of variation in relative abundance of avian predators among fields. To reduce potential shortcomings due to variation in bird detectability, each set of visits to all fields was concentrated in about one week and counts were always made by the same two experienced ornithologists (LR and RM), thereby avoiding biases due to differences in observer efficiency and weather conditions (e.g., Beja et al., 2009). Bias associated with differences in bird detectability due to variation in habitat conditions were considered unlikely, because bird counts were always made in open farmland fields without any significant obstacles, and so visibility was very good and observation conditions were consistent across sites.

Rabbits (Oryctolagus cuniculus), hares (Lepus granatensis) and mammalian carnivores were surveyed on a single occasion (20 June to 9 July), within 300-m radius circles centred on the bird point count located at the forest edge. Each site was thoroughly searched for lagomorph and carnivore faeces and footprints during $1.5 \mathrm{~h}$, following standard procedures used in similar habitats (Beja et al., 2009; Pita et al., 2009). The relative abundance of each species at each site was estimated from the number of signs recorded per hour. All sites were surveyed by the same experienced observer (FC) on a short period, to avoid biases in detection rates due to variation in observer efficiency or changes in weather conditions (Beja et al., 2009; Pita et al., 2009). Although surveys based on field signs have been the subject of some criticism, this approach is generally considered valid based on strong evidence indicating a good fit between carnivore field signs and population density or activity (Barea-Azcón et al., 2007 and references therein).

\subsection{Bird nest predation experiment}

Artificial nests were used to estimate variation in bird nest predation rates within and among fallow fields. For comparative purposes, artificial nests are useful substitutes of real nests, because they ensure flexibility in experimental design and large sample sizes, though they cannot be assumed to provide reliable estimates of survival rates of real nests (Andrén, 1992; Batáry and Báldi, 2004; Pedersen et al., 2009). At each field, artificial nests were placed along a 300-m transect at $0,100,200$ and $300 \mathrm{~m}$ from the forest edge ( $n=200$ nests). These distances and sample sizes were comparable to that of other studies demonstrating edge effects on nest predation rates (Batáry and Báldi, 2004). Each artificial nest was a simple depression on the soil, where two quail (Coturnix sp.) eggs were placed. Nests were set by a single researcher (RM) wearing 
latex gloves and rubber boots, to avoid potential bias due to variation in nest placement criteria, and to reduce problems due to transfer of human scent (Whelan et al., 1994). Artificial nests were set out in 2-6 May, encompassing the incubation period of many ground-nesting birds, and checked after 15 days, which was comparable to the typical incubation period of grassland passerines (Yanes and Suárez, 1997). Each nest was checked only once to reduce observer effects and to preserve nest concealment (Major, 1990). A nest was classified as predated if eggs were missing or damaged, except when there was evidence of ploughing or livestock trampling, in which case they were not considered exposed to predation and were excluded from analysis. Trampling was assessed from the presence of hoof marks and smashed eggs with no signs of predator consumption.

\subsection{Statistical analysis}

Prior to statistical analysis, skewed variables were transformed to approach normality and to reduce the influence of a few large values, using the angular transformation for proportional data and the logarithmic transformation for continuous variables (Table 1). A Principal Component Analysis (PCA) of habitat variables was used to investigate multicollinearity and to describe dominant landscape gradients (Legendre and Legendre, 1998). A varimax normalized rotation was applied to the set of principal components with eigenvalues $>1$, to obtain simpler and more interpretable ecological gradients (Legendre and Legendre, 1998).

Relations between response and explanatory variables were investigated with regression on principal components (Legendre and Legendre, 1998) based on Generalized Linear Models (GLM) of the Gaussian family (McCullagh and Nelder, 1989). This method described the relationships between response variables and gradients extracted from the PCA of forest, landscape, and spatial variables, thereby accounting explicitly for multicollinearity problems (Legendre and Legendre, 1998). Modelling was based on the Information Theoretic Approach (ITA) (Burnham and Anderson, 2002), using the Akaike Information Criteria adjusted for small samples (AICc) as a measure of information loss of each candidate model, with the best fitting model having the lowest AICc and consequently the highest Akaike weight $\left(w_{i}\right)$ (Burnham and Anderson, 2002). Candidate models were built considering all possible subsets of predictor variables, including also the square-power of each principal component to account for eventual unimodal responses to landscape gradients (e.g., Pita et al., 2009). The probability that a variable is included in the best approximating models, given the set of variables considered, was estimated by summing the $w_{i}$ of all candidate models where the variable was included (Burnham and Anderson, 2002). Multimodel Inference (MI) was used to assess the shape and magnitude of the effects of predictors on the response variables, which is based on an estimated weighted average across all models, based on Akaike weights (Burnham and Anderson, 2002). Unconditional standard errors were used to evaluate the precision of model average estimates using a 95\% confidence interval. Estimates whose confidence limits included zero were viewed as having equivocal meaning (Burnham and Anderson, 2002). Although testing all possible models is not the best strategy in model selection, this approach is often used when there is not enough a priori information to build a small set of plausible candidate models (e.g., Whittingham et al., 2005). To reduce the possibility of finding spurious models, the analysis was based on the dominant landscape gradients derived through PCA from an initial large set of variables. In every case, scatterplots and regression diagnostics were used to inspect the shape of the fitted curves and to check for problems resulting from outliers and influential points (Legendre and Legendre, 1998).
Factors influencing bird nest predation rates were also examined using ITA and Multimodel Inference. The analysis started by modelling variation in predation probability in relation to edge, using generalized linear mixed-effects model (GLMM), with a binomial error distribution and a logit-link function, thereby accounting for the potential lack of independence among nests located in each transect (Pinheiro and Bates, 2000; Zuur et al., 2009). In this design, we used a binary response variable coding whether the nest was predated or not, while the distance to edge was the fixed effect and the individual transects were treated as random effects (Reino et al., 2009). In a second set of analyses, variation in the proportion of nests predated in each field was related to landscape gradients and species abundances, using GLM with binomial error distributions and a logit-link function (McCullagh and Nelder, 1989). As nests trampled by cattle or destroyed by agricultural works were removed from analysis, the number of nests used to compute bird nest predation rate varied among fields. To solve this problem, the actual number of nests exposed to predation in each field was used as a weighing factor (Zuur et al., 2009). The analysis of predator influences on predation rates was restricted to the most abundant potential egg and chick predators.

\section{Results}

\subsection{Forest plantation and landscape patterns}

The PCA of forest and landscape variables identified six dominant ecological gradients (eigenvalues $>1$ ), together accounting for $81.9 \%$ of variance in the original data (Table 2 ). The varimax rotation revealed a major gradient (PC1) largely reflecting contrasting fields adjacent to oak plantations, which tended to be young, large and located in landscapes with greater overall cover by forest plantations, with fields adjacent to small, old and tall eucalyptus plantations. The type of forest plantation was also expressed in a secondary gradient contrasting oak and pine stands (PC2), the latter showing higher tree density.

The third ecological gradient (PC3) was the only showing a strong spatial component, reflecting the increase in overall landscape cover by eucalyptus plantations, which were most prevalent to the north-west of the study area. The fourth and fifth rotated PCA axes were largely related to landscape fragmentation. PC4 represented primarily the concurrent increase of edge density and shape complexity of open arable patches, whereas PC5 largely reflected variation in the mean size of open arable patches. PC6 represented the presence of farmland trees, which were more prevalent in landscapes with greater cover of open holm oak woodlands.

\subsection{Lagomorphs and predators}

The assemblage of potential predators of bird eggs and nestlings included 12 avian and eight carnivore species (Supplementary Table S1). The white stork (Ciconia ciconia) was the avian predator recorded most frequently (76\% of fields) and in larger numbers $(0.78 \pm 1.24$ [SD] birds per field per visit). Birds of prey were frequently observed (96\%; $1.32 \pm 1.45$ ), but only Montagu's harriers (Circus pygargus), kestrels (Falco tinnunculus/naumanni), black kites (Milvus migrans) and common buzzards (Buteo buteo) occurred in $>25 \%$ of fields. Corvids were the avian predators recorded least frequently $(60 \%)$ and in lower numbers $(0.66 \pm 0.99)$, with ravens (Corvus corax), carrion crows (Corvus corone) and azure-winged magpies (Cyanopica cyanus) occurring in only $25-40 \%$ of fields.

Carnivore signs recorded most often and in larger numbers were from foxes (Vulpes vulpes) (48\%; $0.61 \pm 1.09$ signs per field) and domestic dogs (38\%; $0.48 \pm 1.03$ signs per field), while signs from the remaining six species were scarce and occurred in $<10 \%$ of fields. 
Table 2

Loadings of habitat variables on the first five axes extracted by a PCA, after a varimax normalized rotation, and the proportion of variance accounted for by each axis. For clarity, only loadings with absolute values greater than 0.50 were listed.

\begin{tabular}{|c|c|c|c|c|c|c|}
\hline Habitat variables & PC1 & PC2 & PC3 & PC4 & PC5 & PC6 \\
\hline Eucalyptus plantations & -0.88 & & & & & \\
\hline Pine plantations & & 0.81 & & & & \\
\hline Oak plantations & 0.61 & -0.67 & & & & \\
\hline Plantation age & -0.76 & & & & & \\
\hline Plantation area & 0.80 & & & & & \\
\hline Tree density & & 0.70 & & & & \\
\hline Tree height & -0.89 & & & & & \\
\hline Farmland trees & & & & & & 0.88 \\
\hline Eucalyptus plantations cover & & & 0.76 & & & \\
\hline Pine plantations cover & & 0.84 & & & & \\
\hline Oak plantations cover & 0.60 & -0.54 & & & & \\
\hline Total forest plantations cover & 0.79 & & & & & \\
\hline Open holm oak woodlands cover & & & & & & 0.71 \\
\hline Mean Patch Size & & & & & 0.86 & \\
\hline Edge Density & & & & 0.86 & & \\
\hline Patch shape complexity & & & & 0.95 & & \\
\hline Northings & & & 0.85 & & & \\
\hline Eastings & & & -0.68 & & & \\
\hline Percentage of total variance & 25.3 & 16.1 & 11.6 & 10.0 & 9.7 & 9.1 \\
\hline
\end{tabular}

All fields yielded lagomorph signs, though those of hares (98\%; $6.76 \pm 7.02$ ) were far more widespread and abundant than those of rabbits (72\%; $2.59 \pm 4.21)$.

\subsection{Predator responses to forest plantations}

Variation in the abundance of the most widespread predators ( $>25 \%$ of fields) appeared to be markedly influenced by gradients extracted from PCA (Table 3), though the shape and strength of such effects varied strongly among species (Supplementary Tables S2 and 3; Supplementary Figures S1-6). Variation in landscape cover by eucalyptus plantations reflected in PC3 had the most consistent effects on predator abundances, with selection probabilities showing a very strong support $(0.97-1.0)$ for a marked positive effect of eucalyptus plantations on the overall abundance of corvids and carnivores, and on that of raven, carrion crow and domestic dog, and a marked negative effect on the abundance of both hares and rabbits. Foxes showed a unimodal response to this landscape gradient, but this effect was only moderately supported.

The effect of eucalyptus plantations was also reflected on PC1, with moderate to strong support $(0.71-1.0)$ for fields sampled close to small and old eucalyptus stands showing higher overall abundance of corvids and carnivores, and that of azure-winged magpie, red fox, domestic dog and rabbit. Hares also showed a strong response to $\mathrm{PC} 1$, with a tendency for higher abundances recorded in fields sampled close to recent and large oak stands, in landscapes with higher oak and overall forest plantation cover. A similar tendency was found for the overall abundance of birds of prey and that of kestrels, but this was only moderately supported (0.72-0.76).

The gradient contrasting oak and pine plantations (PC2) also showed some influence on species abundances, with some support for bird of prey, kestrel and hare abundances increasing with cover by oak plantations, whereas black kites and rabbits increased with pine plantations (Table 3). White storks and black kites tended to decline with increasing edge density (PC4), whereas the opposite

Table 3

Summary results of information-theoretic model selection for the effects of ecological gradients extracted from a PCA of habitat variables (PCn) on species abundances and nest predation rates. For each response variable, the table provides the proportion of explained variance $\left(R^{2}\right)$ of the average model, and the selection probabilities and directions of association with ecological gradients: $(+)$ positive, $(-)$ negative, $(\cap)$ unimodal, and $(\cup)$ U-shaped. For clarity directions of association are given for selection probabilities $>0.70$. See Supplementary Material for details.

\begin{tabular}{|c|c|c|c|c|c|c|c|c|c|c|c|c|c|}
\hline & $R^{2}$ & PC1 & & PC2 & & PC3 & & PC4 & & PC5 & & PC6 & \\
\hline \multicolumn{14}{|l|}{ Birds } \\
\hline White stork & 0.20 & 0.40 & & 0.57 & & 0.38 & & 0.85 & $(-)^{\mathrm{a}}$ & 0.46 & & 0.58 & \\
\hline Birds of prey & 0.25 & 0.72 & $(+)$ & 0.78 & $(-)^{a}$ & 0.44 & & 0.41 & & 0.51 & & 0.42 & \\
\hline Black Kite & 0.15 & 0.40 & & 0.73 & $(+)$ & 0.39 & & 0.70 & $(-)$ & 0.48 & & 0.47 & \\
\hline Montagu's harrier & 0.20 & 0.55 & & 0.44 & & 0.43 & & 0.90 & $(+)^{a}$ & 0.79 & $(+)^{\mathrm{a}}$ & 0.40 & \\
\hline Common buzzard & 0.11 & 0.39 & & 0.62 & & 0.51 & & 0.52 & & 0.40 & & 0.58 & \\
\hline Kestrels & 0.33 & 0.76 & $(+)$ & 0.91 & $(-)^{a}$ & 0.54 & & 0.48 & & 0.60 & & 0.58 & \\
\hline Corvids & 0.47 & 0.95 & $(-)^{a}$ & 0.39 & & 1.00 & $(+)^{\mathrm{a}}$ & 0.62 & & 0.62 & & 0.74 & $(\cap)$ \\
\hline Raven & 0.27 & 0.38 & & 0.41 & & 0.99 & $(+)^{a}$ & 0.44 & & 0.45 & & 0.62 & \\
\hline Carrion crow & 0.41 & 0.38 & & 0.44 & & 1.00 & $(+)^{a, b}$ & 0.49 & & 0.69 & & 0.56 & \\
\hline Azure-winged magpie & 0.48 & 1.00 & $(-)^{\mathrm{a}}$ & 0.59 & & 0.47 & & 0.67 & & 0.38 & & 0.76 & $(+)$ \\
\hline \multicolumn{14}{|l|}{ Mammals } \\
\hline Carnivores & 0.44 & 1.00 & $(-)^{\mathrm{a}}$ & 0.37 & & 0.99 & $(+)^{\mathrm{a}}$ & 0.40 & & 0.78 & $(\cap)$ & 0.41 & \\
\hline Red fox & 0.16 & 0.88 & $(-)^{\mathrm{a}}$ & 0.38 & & 0.71 & $(\cap)$ & 0.38 & & 0.56 & & 0.39 & \\
\hline Domestic dog & 0.26 & 0.71 & $(-)$ & 0.51 & & 0.98 & $(+)^{a}$ & 0.57 & & 0.42 & & 0.46 & \\
\hline Lagomorphs & 0.55 & 0.61 & & 0.41 & & 1.00 & $(-)^{a}$ & 0.74 & $(\cap)$ & 0.80 & $(-)^{\mathrm{a}}$ & 0.39 & \\
\hline Rabbit & 0.39 & 0.76 & $(-)$ & 0.95 & $(+)^{\mathrm{a}}$ & 0.97 & $(-)^{\mathrm{a}}$ & 0.39 & & 0.94 & $(-)^{\mathrm{a}}$ & 0.63 & \\
\hline Hare & 0.58 & 0.99 & $(+)^{a}$ & 0.91 & $(-)^{a}$ & 1.00 & $(-)^{a}$ & 0.49 & & 0.85 & $(\cap)^{b}$ & 0.52 & \\
\hline \multicolumn{14}{|l|}{ Predation } \\
\hline Nest-predation rate & 0.25 & 0.67 & & 0.42 & & 0.75 & $(-)$ & 0.97 & $(\cap)^{\mathrm{b}}$ & 0.40 & & 0.61 & \\
\hline
\end{tabular}

a $95 \%$ confidence intervals of regression coefficients of the linear component $(X)$ do not intersect zero.

b $95 \%$ confidence intervals of regression coefficients of the square-power $\left(X^{2}\right)$ do not intersect zero. 
was found for Montagu's harriers (Table 3). Lagomorphs showed a moderately supported unimodal response to the edge density gradient (Table 3). The effect of open farmland patch size (PC5) was moderately to strongly supported $(0.78-0.94)$, with a negative response by total lagomorph and rabbit abundances, while the opposite was found for Montagu's harriers (Table 3). Finally, there was moderate support for azure-winged magpies increasing with the presence of farmland trees and landscape cover by open holm oak woodlands (PC6), while the overall corvid abundance showed a unimodal response to this gradient (Table 3 ).

\subsection{Bird nest predation rates}

A large proportion of nests set in fields adjacent to forest plantations $(n=200)$ were destroyed or predated (58\%). Discounting the nests trampled by cattle (13\%) or destroyed by agricultural works (4.5\%), predation rate on nests effectively exposed to predators was $49 \%$. Contrary to the initial predictions of higher predation near edges, there was a small tendency for predation rates actually increasing away from forest plantations, but the model including this effect $(\mathrm{AIC}=233.74)$ did not perform better than the corresponding null model $($ AIC $=231.74)$.

Landscape composition and configuration around forest plantations appeared to affect bird nest predation rates (Supplementary Tables S2 and S3; Supplementary Figures S7 and S8). The strongest response was found in relation to the edge density gradient reflected in PC4, with nest predation rates peaking in landscapes with intermediate densities of edge habitats (Table 3 ). Also, there was a moderately supported tendency for predation rates to decline with increasing cover by eucalyptus plantations (PC3) and, to a lesser extent, to increase in fields adjacent to oak stands embedded in landscapes with greater overall cover by forest plantations (PC1) (Table 3).

No consistent relationships were found between predator abundances and bird nest predation rates, either when considering individual species or groups of species (Supplementary Table S4, Supplementary Figures S7 and S8). Only in the case of domestic dogs there was a moderately supported influence on bird nest predation rates, though predation declined with increasing dog abundance (Supplementary Figure S6).

\section{Discussion}

\subsection{Forest plantations, lagomorphs and predator assemblages}

This study supported the view that forest plantations influence predator and prey abundances in surrounding farmland, including that of generalist nest predators such as corvids and carnivores (Batáry and Báldi, 2004), though effects varied strongly among species and they seemed to be influenced by forest characteristics and landscape context. These relationships were evident even without considering vegetation structure and prey availability within forest plantations, which might explain further variation in species abundances (Gehring and Swihart, 2003).

Forest plantations affected predators probably by offering refuges that otherwise would be absent or less abundant in open country. For instance, corvids often nest in tall trees (Alonso et al., 1991; Santos et al., 2006), while feeding in adjacent open farmland (Andrén, 1992; McCollin, 1998), which may justify their strong positive association with eucalyptus plantations and, to a lesser extent, open holm oak woodlands. Eucalyptus plantations also appeared to have a positive effect on carnivores, probably because they are little disturbed by human activities and thus provide secure shelter in landscapes otherwise subject to periodic agricultural operations (Gehring and Swihart, 2003; Baker and Harris, 2006; Pita et al.,
2009). Increasing cover by eucalyptus plantations, however, may ultimately have a negative effect on carnivores, as suggested by the decline in fox abundance in landscapes dominated by this exotic tree, where lagomorphs and other prey tend to be scarce (e.g., Palma et al., 2006; this study).

Rabbits were positively associated with young pine plantations, probably because they were structurally similar to dense Mediterranean shrublands where they can find cover from predators (Calvete et al., 2004; Beja et al., 2007). In general, rabbits in Mediterranean farmland are favoured by mosaics of shrubland and herbaceous patches (Calvete et al., 2004), which may justify their lower abundance in landscapes with either large farmland patches or high cover by mature eucalyptus plantations. In contrast to rabbits, hares were mostly associated with young oak plantations and with landscapes with intermediate size of open farmland patches, though they were also negatively affected by high eucalyptus cover. Oak stands probably provided shelter to hares, because they were very sparse and had a tall and dense herbaceous layer that was largely absent from surrounding farmland (Calzada and Martínez, 1994). Taken together, these results suggest that afforestation may favour lagomorphs in the early stages of development, though these effects may become negative once forests mature (Hulbert et al., 1996). However, high lagomorph abundance around recent plantations appeared to have little influence on predators, as only black kites were associated with young pine plantations, probably reflecting the importance of rabbits in their diet (Viñuela and Veiga, 1992). Birds of prey were most abundant near oak plantations, but this was mostly due to variation in the abundance of kestrels, which do not feed on lagomorphs.

This study also suggested that predators were affected by the amount and configuration of open farmland patches, underlining the key role of processes operating at the landscape scale on local species abundances (e.g., Chalfoun et al., 2002). The overall abundance of carnivores peaked in landscapes with intermediate size of open farmland patches, probably because they are favoured by mosaic landscapes providing a combination of secure shelter in woody habitats and food resources at habitat edges and in adjacent open land (Mangas et al., 2008; Matos et al., 2009; Pita et al., 2009). In contrast, Montagu's harriers were most abundant in large farmland patches, though they were also favoured by increasing edge density, probably because these conditions provided a combination of suitable nesting and foraging habitats (Arroyo et al., 2002). White storks and black kites appeared to be negatively influenced by increasing edge density but reasons for this are unclear, as none of these species seems to avoid edges of any type (e.g., Meunier et al., 2000; Johst et al., 2001). Understanding such relationships would require more detailed information on prey availability across the landscape, which was unfeasible in this study given the diverse array of predators analysed.

\subsection{Bird nest predation}

Contrary to our predictions, predation on artificial bird nests did not increase near forest plantation edges or in areas with high abundance of lagomorphs and putative nest predators. However, predation rates were strongly affected by landscape context, tending to increase with cover by young oak plantations and overall forest plantation cover, to decrease with cover by eucalyptus plantations at both the local and landscape scales, and to peak in landscapes with intermediate edge densities.

The lack of local edge effects and the negative association between predation rates and eucalyptus cover might be considered surprising, because some common nest predators such as carnivores and corvids were strongly associated with forest plantations, particularly with eucalyptus stands. However, this agrees with the lack of relationships observed between nest predation rates and 
predator abundances. Furthermore, lack of edge effects have been reported elsewhere in grassland habitats (Batáry and Báldi, 2004; Renfrew et al., 2005), probably reflecting the range of foraging behaviour of edge predators and the presence of resident grassland predators (Ribic et al., 2009). This may also be the case in southern Portugal, as for instance foxes may move widely and forage in a range of open habitats (Gehring and Swihart, 2003), thereby adding to predation potentially caused by predominantly grassland predators such as white storks and Montagu's harriers. The observed patterns may also reflect the operation of predators not analysed in this study, including snakes, rats (Rattus spp.) and hedgehogs (Erinaceus europeaus) (Batáry and Báldi, 2004; Weatherhead and Blouin-Demers, 2004), or even cattle (Nack and Ribic, 2005). Predation by small mammals was unlikely, because they are generally unable to swallow or break quail eggs (Maier and DeGraaf, 2000).

Despite the lack of local edge effects, there seemed to be a marked influence of landscape context on predation rates, supporting the hypothesis that bird nest predation may depend more on landscape composition and configuration than on the edge per se or on local predator abundances (Donovan et al., 1997; Chalfoun et al., 2002; Batáry and Báldi, 2004). This may be because predation of bird nests is largely incidental, occurring opportunistically when predators are looking for other prey (Vickery et al., 1992). In these circumstances, bird nest predation may be less influenced by predator abundance than by its foraging behaviour (Vickery et al., 1992), which may change with the abundance of different prey types (Yanes and Suárez, 1996) and landscape characteristics (Seymour et al., 2004). Therefore, to understand further the relationships between afforestation and nest predation rates, information should be obtained on the actual species involved in predation events, and how their abundance and foraging behaviour vary in relation to landscape characteristics and prey availability. These studies should also focus on real nests, because they may be more appropriate than artificial nests to estimate the consequences of predation on bird populations (Batáry and Báldi, 2004).

\subsection{Management implications}

This study revealed that forest plantations may offer refuges to generalist predators such as corvids and carnivores, as well as to key prey species such rabbits and hares, which have been associated elsewhere to population declines of ground-nesting birds (Yanes and Suárez, 1996; Fletcher et al., 2010). Besides increasing bird mortality rates, the mere presence of these predators may have non-lethal effects (Cresswell, 2008), eventually contributing to reduced usage of fields around forest plantations by at least some species (Reino et al., 2009). These observations suggest that afforestation programs may have major impacts on farmland biodiversity (Reino et al., 2009; Stoate et al., 2009), which may be particularly negative in Iberian cereal-steppes inhabited by ground-nesting birds threatened at the European level, such as the great bustard (Otis tarda) and the little bustard (Tetrax tetrax), potentially vulnerable to increased predation (Bota et al., 2005). However, this study also showed that the relationships between forest plantations and predation rates may be intricate, which makes it difficult to develop general management prescriptions for reducing its eventual impacts, as these may need to be tailored to meet local ecological conditions.

Our findings supported the recommendation of strongly restricting afforestation in important areas for open grassland birds (Díaz et al., 1998; Reino et al., 2009). Where afforestation has already occurred or new plantations cannot be avoided due to social or economic constraints, efforts should be made to monitor ground-nesting bird populations and nest predation in adjacent open habitats, thereby providing early signals for population declines associated with increased predation rates or non-lethal effects. If necessary, additional conservation action should then be taken, including for instance the fencing of plantation boundaries to restrict movements of terrestrial predators (e.g., Maslo and Lockwood, 2009) or even predator removal (e.g., Fletcher et al., 2010).

\section{Acknowledgements}

This project was funded by Comissão de Coordenação e Desenvolvimento Regional do Alentejo, Associação de Defesa do Património de Mértola, and Portuguese Science and Technology Foundation (FCT) through grants SFRH/BD/14085/2003 and SFRH/BPD/62865/2009 to LR, and SFRH/BD/28974/2006 to MP. We thank Patricia Silva for help during fieldwork, and Liga para a Protecção da Natureza for logistical field support. An earlier version of this paper was greatly improved by constructive criticisms of Mark Wilson and two anonymous referees. We also thank David Anderson and Keith Burnham for clarification of details regarding the IT analysis.

\section{Appendix A. Supplementary data}

Supplementary data associated with this article can be found, in the online version, at doi:10.1016/j.foreco.2010.07.032.

\section{References}

Alonso, J.A., Muñoz-Pulido, R., Bautista, L.M., Alonso, J.C., 1991. Nest-site selection and nesting success in the azure-winged magpie in Central Spain. Bird Study 38, 45-51.

Andrén, H., 1992. Corvid density and nest predation in relation to forest fragmentation: a landscape perspective. Ecology 73, 794-804.

Arroyo, B.E., Garcia, J.T., Bretagnolle, V., 2002. Conservation of the Montagu's harrier in agricultural areas. Animal Conservation 5, 283-290.

Avery, M.I., 1989. Effects of upland afforestation on some birds of the adjacent moorlands. Journal Applied Ecology 26, 957-966.

Avery, M.I., Winder, F.L.R., Egan, V.M., 1989. Predation of artificial nests adjacent to forestry plantations in northern Scotland. Oikos 55, 321-323.

Barea-Azcón, J.M., Virgós, E., Ballesteros-Duperón, E., Moleón, M., Chirosa, M., 2007. Surveying carnivores at large spatial scales: a comparison of four broad-applied methods. Biodiversity and Conservation 16, 1213-1230.

Batáry, P., Báldi, A., 2004. Evidence of an edge effect on avian nest success. Conservation Biology 18, 389-400.

Baker, P.J., Harris, S., 2006. Does culling reduce fox (Vulpes vulpes) density in commercial forests in Wales, UK? European Journal of Wildlife Research 52, 99-108.

Beja, P., Gordinho, L., Reino, L., Loureiro, F., Santos-Reis, M., Borralho, R., 2009. Predator abundance in relation to small game management in southern Portugal: conservation implications. European Journal of Wildlife Research 55, 227-238.

Beja, P., Pais, M., Palma, L., 2007. Rabbit Oryctolagus cuniculus habitats in Mediterranean scrubland: the role of scrub structure and composition. Wildlife Biology $13,28-37$.

Bibby, C.J., Burgess, N.D., Hill, D.A., Mustoe, S.H., 2000. Bird Census Techniques. Academic Press, London.

Bieringer, G., Zulka, K.P., 2004. Shading out species richness: edge effect of a pine plantation on the Orthoptera (Tettigoniidae and Acrididae) assemblage of an adjacent dry grassland. Biodiversity and Conservation 12, 1481-1495.

Bota, G., Morales, M.B., Mañosa, S., Camprodon, J. (Eds.), 2005. Ecology and Conservation of Steppe-land Birds. Lynx Edicions \& Centre Tecnològic Forestal de Catalunya, Barcelona.

Brotons, L., Wolff, A., Paulus, G., Martin, J.-L., 2005. Effects of adjacent agricultural habitat on the distribution of passerines in natural grasslands. Biological Conservation $124,407-414$.

Burnham, K.P., Anderson, D.R., 2002. Model Selection and Multimodel Inference: a Practical Information-Theoretic Approach. Springer, New York.

Calvete, C., Estrada, R., Angulo, E., Cabezas-Ruiz, S., 2004. Habitat factors related to wild rabbit conservation in an agricultural landscape. Landscape Ecology 19, 531-542.

Calzada, E., Martínez, F.J., 1994. Requerimientos y seleccion de habitat de la liebre mediterranea (Lepus granatensis Rosenhaeur, 1856) en un paisaje agricola mesetario. Ecología 8, 381-394.

Caparrós, A., Jacquemont, F., 2003. Conflicts between biodiversity and carbon sequestration programs: economic and legal implications. Ecological Economics 46, 143-157

Chalfoun, A.D., Thompson, F.R., Ratnaswamy, M.J., 2002. Nest predators and fragmentation: a review and meta-analysis. Conservation Biology 16, 306-318.

Cresswell, W., 2008. Non-lethal effects of predation in birds. Ibis 150, 3-17.

Delgado, A., Moreira, F., 2000. Bird assemblages of an Iberian cereal steppe. Agriculture Ecosystems and Environment 78, 65-76. 
Díaz, M. Carbonell, R, Santos, T. Tellería, J.S., 1998. Breeding bird communities in pine plantations of the Spanish plateaux: biogeography, landscape and vegetation effects. Journal of Applied Ecology 35, 562-574.

Donovan, T.M., Jones, P.W., Annand, E.M., Thomson III, F.R., 1997. Variation in localscale edge effects: mechanisms and landscape context. Ecology 78, 2064-2075.

Evans, K.L., 2004. The potential for interactions between predation and habita change to cause population declines of farmland birds. Ibis 146, 1-13.

Ewers, R.M., Didham, R.K., 2006. Confounding factors in the detection of species responses to habitat fragmentation. Biological Reviews 81, 117-142.

Fletcher, K., Aebischer, N.J., Baines, D., Foster, R., Hoodless, A.N., 2010. Changes in breeding success and abundance of ground-nesting moorland birds in relation to the experimental deployment of legal predator control. Journal of Applied Ecology 47, 263-272.

García-Ruiz J.M. Lasanta, T Ruiz-Flano, P Ortigosa L White, S. González, C Martí, C., 1996. Land-use changes and sustainable development in mountain areas: a case study in the Spanish Pyrenees. Landscape Ecology 11, 267-277.

Gehring, T.M., Swihart, R.K., 2003. Body size, niche breadth, and ecologically scaled responses to habitat fragmentation: mammalian predators in an agricultural landscape. Biological Conservation 109, 283-295.

Hansen, K., Rosenqvist, L., Vesterdal, L., Gundersen, P., 2007. Nitrate leaching from three afforestation chronosequences on former arable land in Denmark. Globa Change Biology 13, 1250-1264.

Hulbert, I.A.R., Iason, G.R., Racey, P.A., 1996. Habitat utilization in a stratified upland landscape by two lagomorphs with different feeding strategies. Journal of Applied Ecology 33, 315-324.

Johst, K., Brandl, R., Pfeifer, R., 2001. Foraging in a patchy and dynamic landscape: human land use and the white stork. Ecological Applications 11, 60-69.

Legendre, P., Legendre, L., 1998. Numerical Ecology, 2nd ed. Elsevier, Amsterdam.

Maier, T.J., DeGraaf, R.M., 2000. Predation on Japanese quail eggs vs. house sparrow eggs in artificial nests: small eggs reveal small predators. Condor 102, 325-332.

Major, R.E., 1990. The effect of human observers on the intensity of nest predation. Ibis $132,608-612$

Mangas, K.G., Lozano, J., Cabezas-Dıáz, S., Virgós, E., 2008. The priority value of scrubland habitats for carnivore conservation in Mediterranean ecosystems. Biodiversity and Conservation 17, 43-51.

Matos, H.M., Santos, M.J., Palomares, F., Santos-Reis, M., 2009. Does riparian habitat condition influence mammalian carnivore abundance in Mediterranean ecosystems? Biodiversity and Conservation 18, 373-386.

Maslo, B., Lockwood, J.L., 2009. Evidence-based decisions on the use of predator exclosures in shorebird conservation. Biological Conservation 142, 3213-3218.

Meunier, F.D., Verheyden, C., Jouventin, P., 2000. Use of roadsides by diurnal raptors in agricultural landscapes. Biological Conservation 92, 291-298.

McCollin, D., 1998. Forest edges and habitat selection in birds: a functional approach. Ecography 21, 247-260.

McCullagh, P., Nelder, J.A., 1989. Generalized Linear Models, 2nd ed. Chapman \& Hall, London, UK.

Moreira, F., Beja, P., Morgado, R., Reino, L., Gordinho, L., Delgado, A., Borralho, R., 2005 Effects of field management and landscape context on grassland wintering birds in Southern Portugal. Agriculture Ecosystems and Environment 109, 59-74.

Morgado, R., Beja, P., Reino, L., Gordinho, L., Delgado, A., Borralho, R., Moreira, F. 2010. Calandra lark habitat selection: strong fragmentation effects in a grassland specialist. Acta Oecologica 36, 63-73.

Nack, J.L., Ribic, C.A., 2005. Apparent predation by cattle at grassland bird nests. Wilson Bulletin 117, 56-62.

Niu, X., Duiker, S.W., 2006. Carbon sequestration potential by afforestation of marginal agricultural land in the Midwestern US. Forest Ecology and Management 223, 415-427.

Oxbrough, A.G., Gittings, T., O'Halloran, J., Giller, P.S., Kelly, T.C., 2006. The initial effects of afforestation on the ground-dwelling spider fauna of Irish peatlands and grasslands. Forest Ecology and Management 237, 478-491.

Palma, L., Beja, P., Pais, M., Fonseca, L.C., 2006. Why do raptors take domestic prey? The case of Bonelli's eagles and pigeons. Journal of Applied Ecology 43 1075-1086.

Pedersen, Å.Ø., Yoccoz, N.G., Ims, R.A., 2009. Spatial and temporal patterns of artificial nest predation in mountain birch forests fragmented by spruce plantations. European Journal of Wildlife Research 55, 371-384.

Pescador, M., Peris, S., 2001. Effects of land use on nest predation: an experimental study in Spanish croplands. Folia Zoologica 50, 127-136.
Pinheiro, J.C., Bates, D.M., 2000. Mixed-Effects Models in S and S-Plus. Springer, New York.

Pita, R., Mira, A., Moreira, F., Morgado, R., Beja, P., 2009. Influence of landscape characteristics on carnivore diversity and abundance in Mediterranean farmland. Agriculture Ecosystems and Environment 132, 57-65.

Reino, L., Beja, P., Osborne, P.E., Morgado, R., Fabião, A., Rotenberry, J.T., 2009. Distance to edges, edge contrast and landscape fragmentation: interactions affecting farmland birds around forest plantations. Biological Conservation 142 824-838.

Reino, L., Porto, M., Morgado, R., Moreira, F., Fabião, A., Santana, J., Delgado, A., Gordinho, L., Cal, J., Beja, P., 2010. Effects of changed grazing regimes and habitat fragmentation on Mediterranean grassland birds. Agriculture, Ecosystems and Environment 138, 27-34.

Rempel, R.S., Carr, A.P., 2003. Patch Analyst extension for ArcView: version 3. http://flash.lakeheadu.ca/ rrempel/patch/index.html.

Renfrew, R.B., Ribic, C.A., Nack, J.L., 2005. Edge avoidance by nesting grassland birds: a futile strategy in a fragmented landscape. Auk 122, 618-636.

Ribic, C.A., Koford, R.R., Herkert, J.R., Johnson, D.H., Niemuth, H.D., Naugle, D.E., Bakker, K.K., Sample, D.W., Renfrew, R., 2009. Area sensitivity in North American grassland birds: patterns and processes. Auk 126, 233-244.

Ries, L., Fletcher Jr., R.J., Battin, J., Sisk, T.D., 2004. Ecological responses to habitat edges: mechanisms, models, and variability explained. Annual Review of Ecology and Systematics 35, 491-522.

Santos, T., Tellería, J.L., Dias, M., Carbonell, R., 2006. Evaluating the benefits of CAP reforms: can afforestations restore bird diversity in Mediterranean Spain? Basic and Applied Ecology 7, 483-495.

Seymour, A.S., Haris, S., White, P.C.L., 2004. Potential effects of reserve size on incidental nest predation by red foxes Vulpes vulpes. Ecological Modelling 175, 101-114.

Shochat, E., Abramsky, Z., Pinshow, B., 2001. Breeding bird species diversity in the Negev: effects of scrub fragmentation by planted forests. Journal of Applied Ecology 38, 1135-1147.

Stoate, C., Báldi, A., Beja, P., Boatman, N.D., Herzon, I., van Doorn, A., de Snoo, G.R., Rakosy, L., Ramwell, C., 2009. Ecological impacts of early 21st century agricultural change in Europe-a review. Journal of Environmental Management 91 $22-46$.

Stroud, D.A., Reed, T.M., Harding, N.J., 1990. Do moorland breeding waders avoid plantation edges? Bird Study 37, 177-186.

Suárez, F., Traba, J., Herranz, J., 2005a. Body mass changes in female tawny pipits Anthus campestris during the nesting stage. Journal of Ornithology 146, 372 376.

Suárez, F., Sánchez, A.M., Herranz, J., Traba, J., Yanes, M., 2005b. Parental body mass changes during the nesting stage in two Lark species in a semi-arid habitat. Journal of Arid Environments 62, 45-54

Van Doorn, A.M., Bakker, M.M., 2007. The destination of arable land in a marginal agricultural landscape in South Portugal: an exploration of land use change determinants. Landscape Ecology 22, 1073-1087.

Vickery, P.D., Hunter, M.L., Wells, J.V., 1992. Evidence of incidental nest predation and its effects on nests of threatened grassland birds. Oikos 63, 281-288.

Viñuela, J., Veiga, J.P., 1992. Importance of rabbits in the diet and reproductive success of Black Kites in southwestern Spain. Ornis Scandinavica 23, 132-138.

Weatherhead, P.J., Blouin-Demers, G., 2004. Understanding avian nest predation: why ornithologists should study snakes. Journal of Avian Biology 35, 185190.

Whelan, C.J., Dilger, M.L., Robson, D., Hallyn, N., Dilger, S., 1994. Effects of olfactory cues on artificial nest experiments. Auk 116, 259-264.

Whittingham, M.J., Swetnam, R.D., Wilson, J.D., Chamberlain, D.E., Freckleton, R.P. 2005. Habitat selection by yellowhammers Emberiza citrinella on lowland farmland at two spatial scales: implications for conservation management. Journal of Applied Ecology 42, 270-280.

Yanes, M., Suárez, F., 1995. Nest predation patterns in ground-nesting passerines on the Iberian Peninsula. Ecography 18, 423-428.

Yanes, M., Suárez, F., 1996. Incidental nest predation and lark conservation in an Iberian semiarid shrubsteppe. Conservation Biology 10, 881-887.

Yanes, M., Suárez, F., 1997. Nest predation and reproductive traits in small passerines. A comparative approach. Acta Oecologica 18, 413-426.

Zuur, A.F., Ieno, E.N., Walker, N.J., Saveliev, A.A., Smith, G.M., 2009. Mixed Effects Model and Extensions in Ecology with R. Springer, New York. 